\title{
Family Owned Business Fraud: The Silent Thief
}

M. Tony Bledsoe, (E-mail: bledsoem@meredith.edu), Meredith College Susan B. Wessels, (E-mail: wesselss@meredith.edu), Meredith College

\begin{abstract}
The ACFE 2002 Report to the Nation on Occupational Fraud and Abuse shows "The per-employee losses from fraud in the smallest businesses are 100 times the amount of their largest counterparts." Further, major factors contributing to small business fraud include: inadequate employee prescreening; limited controls and too much trust. The focus of the paper is on issues raised by questions such as should family businesses be concerned about fraud and to what extent can control measures be adopted to help reduce losses caused by this condition? It is an examination of a survey sent to 167 female business owners and their responses to questions about fraud.
\end{abstract}

\section{INTRODUCTION}

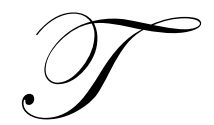

wenty-eight percent of all privately held USA firms are women owned. They employ 9.2 million and generate 1.15 trillion dollars in sales (Center for Women's Business Research, 2001). This signals the economic impact women owned firms have on the US economy. The continuing expansion of these conditions, especially financial, may continue to give rise to employee actions leading to fraud in privately held firms generally and to women owned firms specifically. Given this then it becomes increasingly important for owners to protect assets through fraud recognition and reduction by introducing control measures.

The purpose of this paper is to report findings of an exploratory survey sent to 167 women family business owners (Bledsoe \& Wessels, 2005). Its intent is to establish an awareness of fraud in family owned businesses by offering means for fraud reduction. It is structured to show: Methodology; Findings; Fraud Prevention; Employer Fraud; Association of Fraud and Fraud Prevention in Family Businesses; and Conclusion and Recommendations.

\section{METHODOLOGY}

A 36-item survey was sent by e-mail to 167 women business owners. The first 25 questions were adapted from an earlier survey instrument created by Tower, Hartman, Gudmundson, and Schierstedt (2004). Ten questions were added to their survey instrument in order to explore the association of fraud and fraud prevention within selected characteristics of family businesses. The survey is presented in Appendix A.

\section{FINDINGS}

Fifty-one usable surveys were returned yielding a response rate of 30.5 percent. The mean age of all firms in this survey was 22 years with a range of 1 year to 104 years. Most of the businesses are still first generation of owners (79 percent) with 13 percent owned by the second generation and 8 percent owned by the third generation. Fifty-three percent of the firms reported annual revenue of less than $\$ 1$ million followed by 34 percent with $\$ 1$ to $\$ 4$ million, and 13 percent at $\$ 5$ million and above.

Of those surveyed, 21 percent of the firms have a formal board of directors. An independent samples t-test showed that those firms with formal boards of directors were significantly more likely to report higher annual revenue $(p=.028)$. There was also a significant difference in the average age of those firms with formal boards (mean $=43$ 
years) and those without formal boards (mean $=15$ years). These firms were also significantly more likely to report that the second or third generation is currently in control of the firm $(p=.002)$.

Over 68 percent of the respondents classified their firm as a family business and 98 percent of the respondents stated their firms were privately held. An independent samples t-test showed that there was no significant difference between those firms classified as a family business and firms not so classified regarding the presence of a formal board of directors. Family businesses, however, were significantly more likely to have higher annual revenue than other firms in this survey $(p<.0001)$. No significant difference was found in age between those firms categorized as family businesses ( $m e a n=24$ years) compared to other firms (mean $=18$ years).

\section{FRAUD PREVENTION}

Six questions were sent regarding the firm's fraud prevention techniques. Those questions were individually tallied and were also used to create a new variable called "Fraud Prevention." The Fraud Prevention variable was a score in which the firm received one point for each anti-fraud procedure that was in place at that firm (written code of ethics, prescreen employee applicants, educate employees to prevent and detect fraud, offer way for employees to anonymously report fraud, segregate bookkeeping from bank reconciliation and segregate check writing from recording payables). The fraud prevention scores ranged from 0 to 6 with 6 percent of firms reporting none of these anti-fraud measures in place and 12 percent of firms using all of these measures. The mean score was 2.8 indicating that only 2 or 3 of these fraud prevention measures are being used by the typical firm. There was a significant difference $(p=.001)$ in fraud prevention scores between firms with formal boards of directors (mean 4.4) and those firms with no formal boards of directors (mean 2.35).

\section{EMPLOYEE FRAUD}

Seven respondents indicated that their firm had experienced a loss from employee fraud in the last year. The mean loss amount was $\$ 2,236$ with one respondent reporting $\$ 100,000$. The respondents were also asked to indicate if they had ever been a victim of one of nine different kinds of employee frauds (skimming revenue, cash larceny, stealing inventory, fraudulent billing, payroll fraud, fraudulent expense reimbursement, employee accepting kickbacks from suppliers, check tampering, and other). Approximately 35 percent of the firms reported being the victim of one or more types of employee fraud. The most common was stealing inventory ( 28 percent). Table 1 presents the employee fraud experience of the firms in this survey. Those firms which were classified as family businesses were significantly more likely $(p=.009)$ to have been the victim of one or more types of employee fraud. However, there was no significant difference between firms with formal boards of directors and other firms on the issue of whether they experienced employee fraud.

Table 1: Number and Percentage of Firms Experiencing Employee Fraud

\begin{tabular}{|l|c|c|}
\hline Type of Employee Fraud & Number & Percentage \\
\hline Skimming revenue & 3 & $10.7 \%$ \\
\hline Cash larceny & 4 & $14.3 \%$ \\
\hline Stealing inventory & 10 & $35.7 \%$ \\
\hline Fraudulent billing & 0 & $0 \%$ \\
\hline Payroll fraud & 3 & $10.7 \%$ \\
\hline Fraudulent expense reimbursement & 1 & $3.6 \%$ \\
\hline Employee accepting kickbacks & 0 & $0 \%$ \\
\hline Check tampering & 3 & $10.7 \%$ \\
\hline Other (please list) & 4 & $14.3 \%$ \\
\hline
\end{tabular}

In those cases where employee fraud occurred, the respondents were asked to indicate how the fraud was first detected (by accident, external audit, internal audit, internal controls, notified by police, and tips from another employee or outsider). Internal controls were the most frequently cited method by which the frauds were discovered (17.6 percent). Table 2 presents information about fraud detection. 
Table 2: Method by Which Fraud Was First Detected

\begin{tabular}{|l|c|c|}
\hline Fraud first detected & Number & Percentage \\
\hline By accident & 4 & $14.8 \%$ \\
\hline External audit & 1 & $3.7 \%$ \\
\hline Internal audit & 6 & $22.2 \%$ \\
\hline Internal controls & 10 & $37.0 \%$ \\
\hline Notified by police & 0 & $0 \%$ \\
\hline Tip by another employee or outsider & 6 & $22.2 \%$ \\
\hline
\end{tabular}

\section{ASSOCIATION OF FRAUD AND FRAUD PREVENTION IN FAMILY BUSINESS}

A logistic regression model was used to estimate the factors which influence whether a firm experienced fraud. The dependent variable was "Experienced Fraud" and was equal to 1 if the respondent's firm ever experienced any of nine types of employee fraud and 0 if no fraud was experienced. Using a likelihood ratio forward stepwise selection, five variables were used as possible predictors of experiencing fraud. The predictors of fraud were the age of firm, annual revenue by category, formal board of directors, family business classification, and the fraud prevention score.

Only one factor, the fraud prevention score, was significantly associated with whether a firm experienced fraud. The overall model was significant at the $p=.016$ level according to the model Chi-square statistic. The model predicts 66.7 percent of the responses correctly. The Nagelkerke $\mathrm{R}^{2}$ was .177 .

Having found that fraud prevention techniques are most significantly related to whether a firm experienced any type of fraud, the next issue is what characteristics of firms are associated with having fraud prevention techniques. A multiple regression analysis was performed using the fraud prevention score as the dependent variable and the age of the firm, annual revenue, formal board of directors, family business classification as explanatory variables. Using the standard enter method, a significant model emerged $[F(4,37)=3.625, p=.014]$. We found that having a formal board of directors was significantly associated with fraud prevention techniques. Table 3 presents the regression results.

Table 3: Multiple Regression Analysis of Firm Characteristics on Fraud Prevention Score

\begin{tabular}{|l|c|c|c|c|}
\hline Firm Characteristics & B & Beta & $\boldsymbol{T}$ & $\boldsymbol{P}$ \\
\hline Formal board of directors & 1.842 & .429 & 2.323 & .026 \\
\hline Age of firm & .009 & .104 & .492 & .625 \\
\hline Annual revenue (by categories) & .030 & .018 & .088 & .930 \\
\hline Family business & .399 & .100 & .647 & .522 \\
\hline
\end{tabular}

\section{CONCLUSIONS AND RECOMMENDATIONS}

Family owned businesses have a significant impact on the US economy and these firms face numerous survival challenges. Poza reports "approximately 85 percent of all family businesses fail within their first five years of operation" (Poza, 2004). Differing factors may be attributed to this condition and the researchers believe that fraud may be counted among them. That assumption led to their developing and sending a fraud related questionnaire to 167 women family business owners. The purpose of the collected data was to begin to examine the cause and effect of fraud in women owned family firms. The analyzed data was summarized and reported under the headings: (1) Findings; (2) Fraud Prevention; (3) Employee Fraud; and (4) Association of Fraud and Fraud Prevention in Family Businesses. 
The findings may appear counter-intuitive: firms which have experienced fraud are significantly more likely to have a higher fraud score. One possible scenario may be that firms experiencing fraud have taken steps to prevent further fraud occurrences. Thus speculating that when a firm reaches the point in growth that it needs a board of directors it likely also experiences the need for fraud prevention.

Concluding that fraud, within the family owned business community, exists is not difficult to ascertain. Proving how deep this situation runs and to what degree of impact on the survival of these firms presents a more pressing problem and needs more extensive research, investigation and analysis. Wells offers "...small businesses remain the most vulnerable to occupational fraud because of three factors: They are the least likely to have an audit, a hotline or adequate internal controls" (Wells, 2004). Given this condition, academic institutions have an opportunity to forge partnerships with the business community to provide an arena for research and educational programs that could help to address the fraud problem. This coalition would provide a platform for such fraud awareness activities as: workshops, forums, seminars, courses and presentations. Finally it appears that detection leads to reduction and both of these may be enhanced through education and training.

\section{REFERENCES}

1. Astrachan, Joseph, Andrew Keyt, Suzanne Lane, and Kristi McMillan. Loyola Guidelines for Family Business Board of Directors. Available at http://www.sba.luc.edu/familybusiness

2. Bledsoe, M.T. and S. Wessels. (2005). Family Business and Practices Spring 2005 Unpublished Family Owned Business Research, School of Business at Meredith College, Raleigh, N.C.

3. Center for Women's Business Research. (2001). Women-Owned Businesses in North Carolina, 2002: A Fact Sheet. Women-Owned Businesses in 2002: Trends in the U.S. and 50 States. Washington, D.C.: n.p., 1-3.

4. Hartman, Alan E., Donald Gudmundson, C. Burk Tower, and Susan Schierstedt, eds. Family Business Boards: Relationship to Planning and Organizational Outcomes. Proc. Of $18^{\text {th }}$ Annual USASBE National Conference, Jan. 2004, Dallas, Texas.

5. Mass Mutual Financial Group. (2003). New Nationwide Survey Points to Bright Spot in American Economy - Family-Owned Business. A Press Release. Available at http://www.massmutual.com/mmfg/about/ pr_2003/01_22_03.html

6. $\quad$ Poza, Ernesto J. (2004). Family Business. Ohio: South-Western.

7. Sharma, Pramodita, and Shaker A. Zahrs. (2004). Family Business Research: A Strategic Reflection. Family Business Review. Dec., XVII (4), 331-346.

8. Wells, Joseph T. (2003). Protect Small Business. Journal of Accountancy, March, 26-32.

9. Wells, Joseph T. (2004). Small Business, Big Losses. Journal of Accountancy, Dec., 42-47.

\section{APPENDIX A}

\section{Fraud Survey Questions}

1. Has your firm ever been a victim of any of the following employee frauds? Please check all that apply.

\footnotetext{
- $\quad$ Skimming revenue (stealing cash before it has been recorded on the books)

- $\quad$ Cash larceny (stealing cash after it has been recorded on the books.)

- $\quad$ Stealing inventory

- $\quad$ Fraudulent billing (firm paid for fictitious goods or services.)

- $\quad$ Payroll fraud

- $\quad$ Fraudulent expense reimbursement

- $\quad$ Employee accepting kickbacks from suppliers

- $\quad$ Check tampering

- $\quad$ Other (please list)
} 
2. If you firm has ever experienced employee fraud, how did you first detect the fraud?

- $\quad$ By accident

- $\quad$ External audit

- Internal audit

- Internal controls

- $\quad$ Notified by police

- $\quad$ Tip from another employee or outsider

3. If your firm has ever experienced employee fraud, was the perpetrator a family member?

Yes No

4. In the last year what was the approximate amount (if any) of the loss to your firm from employee fraud?

\section{These questions relate to your firm's anti-fraud procedures:}

5. Does your firm have a written code of ethics?

Yes No

6. Does the same employee in your firm handle both check writing and the payables function?

Yes No

7. Does the same employee in your firm handle both bookkeeping functions and perform bank reconciliations?

Yes No

8. Do you pre-screen employee applicants?

Yes No

9. Do you educate employees to prevent and detect fraud?

Yes No

10. Do you give employees a way to anonymously report fraud?

Yes No

11. Is there anything you would like to add about the existence and nature of your board of directors? 


\section{NOTES}

